socio-cultural dimensions: monograph. Zaporozhye: Publishing ZDIA, 616.

20. Burbach, R. (1999). The fin di siecle debate: globalization as epochal shift // Science and Society, 63 (1), 10-39.

21. Robinson, W. I. (2004). A theory of global capitalism: Production, class and state in a transitional world. Baltimore, London: Johns Hopkins univ. press, 200.

22. Modelski, G. (2005). The evolution of global politics (II). Polis, 4, 139-140.

23. Elizarenko, T. P. (2004). Internationalization of savings as the material basis of modern globalization. Moscow: Scientific book, 200.

24. Chumakov, A. N. (2006). East India Company. Global Studies. International Interdisciplinary
Encyclopedic Dictionary. Moscow: SPb., NY : IC „JeLIMA”, ID ,Piter”, 663-664.

25. Globalization, G., Poverty (2001). A. World Bank Policy Research Report. Oxford University Press, 174.

26. Globalization, G., Poverty (2004). [translation from engl]. Moscow: All the World, 206.

27. Maddison, A. (2001). The World Economy: Millennial Perspective. Paris: OECD, 383.

28. Commodity Yearbook (2003). UN : New York and Geneva, 464.

29. Handbook of Statistics (2009). UN : New York and Geneva, 492.

30. Bali Ministerial Declaration and Decisions. Available at: http:// mc9.wto/org/draft-bali-ministerialdeclaration

Дата надходження рукопису 26.08.2014

Власов Владимир Иванович, д-р экон. и сельск. наук, проф., отдел внешнеэкономических связей, Национальный научный центр «Институт аграрной экономики». ул. Героев Обороны, г. Киев, Украина, 03680

E-mail: zed@iae.kiev.ua

УДК 330.142

\title{
ПРОЦЕСИ ФОРМУВАННЯ, НАКОПИЧЕННЯ ТА ОБМІНУ ІНТЕЛЕКТУАЛЬНИМ КАПІТАЛОМ ТРАНСНАЦІОНАЛЬНИМИ КОРПОРАЦЯМИ
}

\author{
(C) Е. О. Панченко
}

В статті розглянуто наукові підходи до структури інтелектуального капіталу транснаціональних корпорацій. Досліджено основні підходи до управління, формування, накопичення та обміну інтелектуальним капіталом ТНК. Запропоновано авторське визначення структури інтелектуального капіталу підприємницьких структур (в тому числі транснаціональних корпорацій). Систематизовано та охарактеризовано основні процеси управління інтелектуальним капіталом транснаціональних корпораціiй.

Ключові слова: інтелектуальний капітал, транснащіональна корпорація, структура, процеси управління, формування, обмін, накопичення.

The article deals with scientific approaches to intellectual capital structure of multinational corporations. The main approaches to the management, creation, storage and sharing of intellectual capital MNCs are investigated. The author determine the structure of intellectual capital businesses (including transnational corporations) is given. The main processes of intellectual capital management of transnational corporations are systematizies and described.

Keywords: intellectual capital, multinational corporation, structure, management processes, forming, exchange, accumulation.

\section{1. Вступ}

На сучасному етапі розвитку роль інтелектуального капіталу, особливо в рамках його корпоративної форми, безперервно зростає. У крупних транснаціональних корпораціях великого значення набувають наукомісткі процеси, пошук i впровадження новітніх виробів, технологій тощо.

2. Постановка проблеми та її зв'язок із важливими науковими та практичними завданнями

Ефективність функціонування корпоративних підприємств (у тому числі транснаціональних корпорацій) значною мірою визначається їх інноваційним рівнем, який безпосередньо пов'язаний 3 рівнем процесів управління інтелектуальним капіталом як одним із важливих стратегічних чинників економічного зростання. Зростання уваги в наукових колах до питань управління інтелектуальним капіталом підприємницьких структур пояснює актуальність їх систематизації.

\section{3. Аналіз останніх досліджень і публікацій} Підходи до процесів управління інтелектуальним капіталом висвітлені в працях низки вітчизняних та іноземних авторів, серед яких А. 
Чухно, Д. Л. Волков, Т. А. Гараніна, Л. Едвінссон, Е. Брукінг, Т. А. Стюарт, С. І. Кравченко, О. В. Корнєва, Н. О. Шпак, Н. Б. Білоус, О. О. Філіпов, О. М. Олійник, К. В. Ковтуненко, В. А. Осипов, В. Г. Дайнеко тощо. Незважаючи на велику кількість досліджень в цьому напрямі, існують різні наукові підходи до розуміння як основних процесів управління, так i, структури інтелектуального капіталу.

4. Мета статті - систематизація основних процесів інтелектуального капіталу та визначення його структури.

\section{5. Викладення основного матеріалу та результати дослідження -Формування, накопичення та обмін інтелектуальним капіталом транснаціональними корпораціями}

До основних процесів управління інтелектуальним капіталом можна віднести формування, накопичення, обмін. При цьому від рівня управління кожного 3 вказаних процесів залежить загальна ефективність управління i використання інтелектуального капіталу підприємницьких структур сучасного типу.

Процес формування інтелектуального капіталу підприємницьких структур (у тому числі транснаціональних корпорацій) розглядається в розрізі формування структурних складових цього капіталу.

В наукових колах на сьогоднішньому етапі розвитку немає єдиного підходу щодо структурних складових інтелектуального капіталу підприємницьких структуру (у тому числі транснаціональних корпорацій).

Незважаючи на відсутність єдиного наукового підходу багато авторів розглядаючи ту або іншу структуру зазначають, що остання $\epsilon$ найбільш вживаною в наукових колах та серед практиків.

Зокрема, за твердженням А. Чухно [1], науковці та практики вважають найбільш прийнятним формування інтелектуального капіталу підприємств за такими складовими, як людський капітал, структурний капітал та споживчий капітал. Відповідна структура заслуговує на увагу, хоча $є$ певною мірою узагальнюючою. Наприклад, в структурному капіталі не систематизовані окремі об'єкти нематеріальних ресурсів, формування яких відбувається у відповідності до певних норм та вимог законодавства. Зокрема, не виділено окремо об'єкти промислової власності, об'єкти, що охороняються авторським правом та суміжними правами та інші об'єкти інтелектуальної власності. Тобто, структура складових інтелектуального капіталу підприємств згідно, представлена А. Чухно [1] може використовуватись при його формуванні на невеликих або середніх підприємствах, а для крупних підприємницьких структур, особливо транснаціональних корпорацій необхідне використання більш чіткої та систематизованої структури.

Д. Л. Волков, Т. А. Гараніна [2] представили структуру інтелектуального капіталу підприємств схожу за складовими із структурою, запропонованою А. Чухно [1].

Відповідно із підходом Д. Л. Волкова, T. А. Гараніної [2], структура складових інтелектуального капіталу підприємств може бути представлена: людським, організаційним (структурним) та капіталом відносин. Капітал відносин [2] схожий за складом із споживчим капіталом, запропонованим в структурі А. Чухно [1]. Структура, запропонована Д. Л. Волковим, T. А. Гараніною [2], як і попередня носить узагальнюючий характер, відсутня систематизація видів певних складових, яка $є$ загальноприйнятною щодо ідентифікації нематеріальних ресурсів певних категорій.

Необхідно відмітити, що підхід Д. Л. Волкова, T. А. Гараніної [2], А. Чухно [1] сформований 3 урахуванням поглядів на це питання зарубіжних авторів. Зокрема, в табл. 1 представлене співставлення підходів Л. Едвінссона [3], Е. Брукінг [4], Т. А. Стюарт [5] щодо структури складових інтелектуального капіталу підприємств.

Таблиця 1

Підходи Л. Едвінссона [3], Е. Брукінг [4], Т.А. Стюарт [5] щодо структури складових інтелектуального капіталу підприємств

\begin{tabular}{|c|c|c|c|}
\hline $\begin{array}{lr}\text { Структура } & \text { складових } \\
\text { iнтелектуального } & \text { капіталу }\end{array}$ & $\begin{array}{lr}\text { Структура } & \text { складових } \\
\text { iнтелектуального } & \text { капіталу }\end{array}$ & \multirow{2}{*}{\multicolumn{2}{|c|}{$\begin{array}{l}\text { Структура складових інтелектуального } \\
\text { капіталу підприємств згідно із підходом } \\
\text { Л. Едвінссона [3] }\end{array}$}} \\
\hline $\begin{array}{lr}\text { підприємств } \quad \text { згідно } \\
\text { підходом Е. Брукінг [4] }\end{array}$ & $\begin{array}{l}\text { підприємств згідно із підходом } \\
\text { Т.А. Стюарт [5] }\end{array}$ & & \\
\hline 1. Людські активи & 1. Людський капітал & \multicolumn{2}{|c|}{ 1. Людський капітал } \\
\hline 2. Інфраструктурні активи & \multirow[t]{2}{*}{ 2. Структурний капітал } & \multirow[t]{3}{*}{$\begin{array}{l}\text { 2. Структурний } \\
\text { капітал }\end{array}$} & \multirow{2}{*}{$\begin{array}{l}\text { 2.1. Організаційний } \\
\text { капітал (інноваційний } \\
\text { та процесний капітал) }\end{array}$} \\
\hline 3. Інтелектуальна власність & & & \\
\hline 4. Ринкові активи & 3. Споживчий капітал & & $\begin{array}{l}2.2 . \\
\text { капітал }\end{array}$ \\
\hline
\end{tabular}

Згідно із підходом Л. Едвінссона [3], структура інтелектуального капіталу підприємств складається 3 двох компонентів, а саме:
1) людського капіталу - компетенції і досвід співробітників компанії, які втрачаються із звільненням співробітників; 
2) структурного капіталу, який належать усій компанії, хоча $є$ продуктом діяльності іiі співробітників:

- цінність відносин 3 клієнтами (клієнтський капітал);

- цінність продуктів інтелектуальної власності (ідеї, патенти, ліцензії тощо) (інноваційний капітал);

- а також цінність інфраструктури компанії (процесний капітал).

Необхідно відмітити, що в підході Л. Едвінссона [3] чітко розділено склад людського та структурного капіталу. Хоча, на сьогоднішній день 3 урахуванням змін в складі інформаційних технологій, організації кадрової політики, чіткого розмежування та виділення окремих нематеріальних ресурсів відбулись зміни та розширився склад структурних складових інтелектуального капіталу підприємств.

Згідно із підходом Т. А. Стюарт [5], структура інтелектуального капіталу підприємств може бути представлена людським, структурним та споживчим капіталом. Детальний склад кожного елементу структури, представленої Т. А. Стюарт [5], аналогічний тому, який пізніше був визначений в структурі А. Чухно [1].

Е. Брукінг [4] вважає, що структура компонентів інтелектуального капіталу підприємств складається з людських, інфраструктурних, ринкових активів та інтелектуальної власності. Автор [4] детально зупиняється на розкритті складу всіх структурних елементів досліджуваного виду капіталу.

Слід зробити особливий акцент на тому, що Е. Брукінг [4] в своій структурі визначив окремою складовою інтелектуальну власність. Ця складова на сьогоднішній день, на нашу думку, повинна посідати окреме місце в структурі складових інтелектуального капіталу підприємств, оскільки до неї входить низка видів нематеріальних ресурсів, серед яких об'єкти промислової власності, об'єкти, що охороняються авторським правом та суміжними правами та інші об'єкти інтелектуальної власності.

Можна констатувати, що при співставленні внутрішнього змісту окремих компонентів інтелектуального капіталу підприємств можна зробити висновок про певну ідентичність структур досліджуваного виду капіталу, запропонованих Л. Едвінссоном [3], Е. Брукінг [4], Т. А. Стюарт [5], та представлених в підходах Д. Л. Волкова, Т. А. Гараніної [2], А. Чухно [1].

Українські автори, переважно, використовують загальноприйняті підходи до структурування складових інтелектуального капіталу підприємств, хоча представляють елементи цих складових у відповідності до чинного законодавства України в розрізі тих складових, які регулюються останнім. Зокрема, Кравченко С. І., Корнєва О. В. [6] адаптували структуру інтелектуального капіталу підприємств, запропоновану Е. Брукінг [4] до економічних категорій, визначених законодавством України за станом на 31.12.2008 p.

Зазначена структура [6] заслуговує на увагу, оскільки систематизує ті види інтелектуальних ресурсів, які можуть бути оцінені і відображені в фінансовій звітності підприємницьких структур. Хоча, ринкові, інфраструктурні та людські активи, за підходом Кравченко С. І., Корнєва О. В. [6] не можуть бути оцінені за допомогою кількісних методів. Необхідно зауважити, що представлена структура елементів інтелектуальної власності [6] за станом на 31.12.2013 р. мала інший склад з огляду на зміни в законодавстві. Можемо констатувати вплив часового фактору на структурування елементів інтелектуального капіталу підприємницьких структур в сучасних умовах.

Існують наукові праці вітчизняних вчених, в яких здійснена спроба систематизація основних підходів до структуризації елементів інтелектуального капіталу підприємницьких структур. Серед таких можна виділити систематизацію, представлену Н. О. Шпак, Н. Б. Білоус [7].

Як справедливо зауважують Н. О. Шпак, Н. Б. Білоус [7], переважна більшість авторів дотримуються підходу структуризації елементів інтелектуального капіталу підприємницьких структур за типами, серед яких людський, ринковий та структурний капітали виділяються у якості основних.

Зокрема, в якості прикладу можна запропонувати стандартний підхід до структуризації елементів інтелектуального капіталу підприємницьких структур, представлений О.О. Філіповим [8]. Автор запропонував системний склад кожної із складових інтелектуального капіталу підприємницьких структур. Хоча, на нашу думку, в такому підході відсутнє окреме виділення такої важливої складової, як інтелектуальна власність, запропонованої Кравченко С. І., Корнєва О. В. [6].

Необхідно відмітити грунтовну структуру складових інтелектуального капіталу підприємницьких структур, запропоновану О. М. Олійник. Автор [9] пропонує розглядати інтелектуальний капітал підприємницьких структур в розрізі ресурсної та процесної складових. При цьому, ресурсна складова включають кадровий капітал (або людський капітал), нематеріальні ресурси (об'єкти інтелектуальної власності розподілені за групами).

До процесної складової входять управлінська, комунікаційна та технологічна складові. Відповідно, О.М. Олійник [9], які і інші автори враховує основні елементи інтелектуального капіталу, розподіливши їх за окремими складовими, окремо виділяє об'єкти інтелектуальної власності, які є важливою частиною цього виду капіталу.

Можна констатувати, що автор [9], на відміну від класиків економічної науки, які починали досліджувати дане питання i розглядали інтелектуальний капітал підприємницьких структур за допомогою ресурсного та вартісного підходу, розглядає його за допомогою ресурсного та процесного підходів.

Дослідження дозволило запропонувати авторське визначення структури інтелектуального капіталу підприємницьких структур (в тому числі 
транснаціональних корпорацій), яке сформоване 3 урахуванням основних наукових підходів, норм законодавства щодо регулювання об'єктів інтелектуальної власності в Україні. Зокрема, на нашу думку, інтелектуальний капітал підприємницьких структур (в тому числі транснаціональних корпорацій) сформований 3 [авторська розробка]:

1) кадрового капіталу, який складається 3 :

- людських ресурсів (рівня знань, досвіду, навичок, наукових досягнень кадрів, вмінь);

- структурних активів (корпоративної культури, системи управління кадрами);

2) нематеріальних ресурсів (об'єктів інтелектуальної власності) (ст. 5 Положення (стандарт) бухгалтерського обліку 8 «Нематеріальні активи» за станом на 31.12.2013 р.):

- прав користувань природними ресурсами (прав користувань надрами, іншими ресурсами природного середовища, геологічною та іншою інформацією щодо природного середовища тощо);

- прав користувань майном (прав користувань земельними ділянками згідно із нормами земельного законодавства, прав користувань будівлями, прав на оренду приміщень тощо);

- прав на комерційні позначення (прав на торговельні марки (знаки для товарів і послуг), комерційні (фірмові) найменування тощо), крім тих, витрати на придбання яких визнані роялті;

- прав на об'єкти промислової власності (прав на винаходи, промислові зразки, корисні моделі, породи тварин, сорти рослин, компонування (топографіi) інтегральних мікросхем, комерційні таємниці, у тому числі захист від недобросовісної конкуренції, ноу-хау тощо), крім тих, витрати на придбання яких визнані роялті;

- авторських прав та суміжних 3 ними прав (прав на художні, літературні, музичні твори, комп'ютерні програми, програми для електроннообчислювальних машин, компіляції даних (бази даних), виконання, відеограми, фонограми, передачі (програми) організацій мовлення тощо), крім тих, витрати на придбання яких визнані роялті;

- інших нематеріальних активів (прав на провадження діяльності, використання економічних та інших привілеїв тощо);

3) управлінського капіталу, який представлений системою організаційного управління підприємницькою структурою;

4) комунікаційного (ринкового) капіталу, який представлений системою маркетингового управління підприємницькою структурою;

5) технологічного капіталу, який включає технології та процеси, які використовуються підприємницькою структурою.

Запропонована структура інтелектуального капіталу підприємницьких структур (в тому числі транснаціональних корпорацій) враховує як стандартні складові капіталу, так i передбачає елементи такої важливої складової, як нематеріальних ресурсів (об'єктів інтелектуальної власності) у відповідності 3 нормами чинного законодавства України.

Розглянемо питання формування

інтелектуального капіталу підприємницьких структур.

Дане питання в наукових колах розглядається, переважно, в розрізі розкриття структури інтелектуального капіталу підприємницьких структур. Хоча характеристика процесу формування також $є$ особливо актуальною для розвитку наукових досліджень та з практичної точки зору.

Можна виділити науковий підхід до формування інтелектуального капіталу підприємницьких структур, запропонований К. В. Ковтуненко [10]. Автор [10] при розкритті процесу формування розглядає останній через трансформацію тріади економічних категорій, серед яких інтелектуальні ресурси, інтелектуальний потенціал та інтелектуальний капітал.

На рис. 1 представлено схему формування інтелектуального капіталу підприємницьких структур, запропоновану К. В. Ковтуненко [10].

Як стверджує К. В. Ковтуненко [10], процеси трансформації складових інтелектуального потенціалу в складові інтелектуального капіталу підприємницьких структур здійснюються завдяки ефективній управлінські стратегії, при цьому всі інтелектуальні ресурси, які залучаються до створення капіталу, повинні сприяти посиленню інноваційній активності. Тобто, на думку автора [10], ефективне формування інтелектуального капіталу можливе лише при успішному використанні інтелектуального потенціалу в процесі управління підприємством (в тому числі транснаціональною корпорацією). I ця система управління повинна, в свою чергу, забезпечити максимальну здатність ефективного використання інтелектуального потенціалу (фактичних інтелектуальних ресурсів) в інноваційних процесах, які здійснюються на підприємстві. Окремо, на нашу думку, актуальним для подальшого планування інтелектуального капіталу важливим є планування інноваційного потенціалу підприємств, яке повинно здійснюватись 3 урахуванням внутрішнього та зовнішнього середовищ підприємств. Згідно із підходом автора [10], процес відбору інтелектуальних ресурсів необхідно здійснювати 3 урахуванням певних критеріїв, які обумовлюються конкретними ринковими умовами та можливостями підприємницьких структур. Необхідно відмітити, що рівень формування інтелектуального капіталу $\epsilon$ більш високим у транснаціональних корпорацій порівняно із звичайними компаніями, які діють на внутрішніх ринках.

На думку К. В. Ковтуненко [10], при відборі інтелектуальних ресурсів як результату використанні інтелектуального потенціалу їх форма залишається статично. А в результаті інноваційних процесів трансформації інтелектуального потенціалу формується інтелектуальний капітал, який має динамічні характеристики. Зокрема, інтелектуальні ресурси володіють потенціалом розвитку, впливають 
на створення нової вартості підприємства, збільшення прибутку та зростання конкурентних позицій, i можуть бути динамічними, тобто змінювати власну форму. Наприклад, в розрізі зміни кадрового капіталу, це підвищення рівня кваліфікації персоналу; в розрізі зміни нематеріальних ресурсів створення нових промислових зразків, торгових марок тощо; в розрізі зміни управлінського капіталу - створення нової стратегії організаційного управління підприємницькою структурою; в розрізі зміни комунікаційного (ринкового) капіталу - вибір інноваційної маркетингової стратегії залучення нових сегментів споживачів; в розрізі зміни технологічного капіталу - розробка, впровадження нової технології виробничого процесу тощо.

На нашу думку, запропонований підхід [10] $є$ прийнятним для використання сучасними підприємницькими структурами (в тому числі транснаціональними корпораціями) для здійснення формування інтелектуального капіталу.

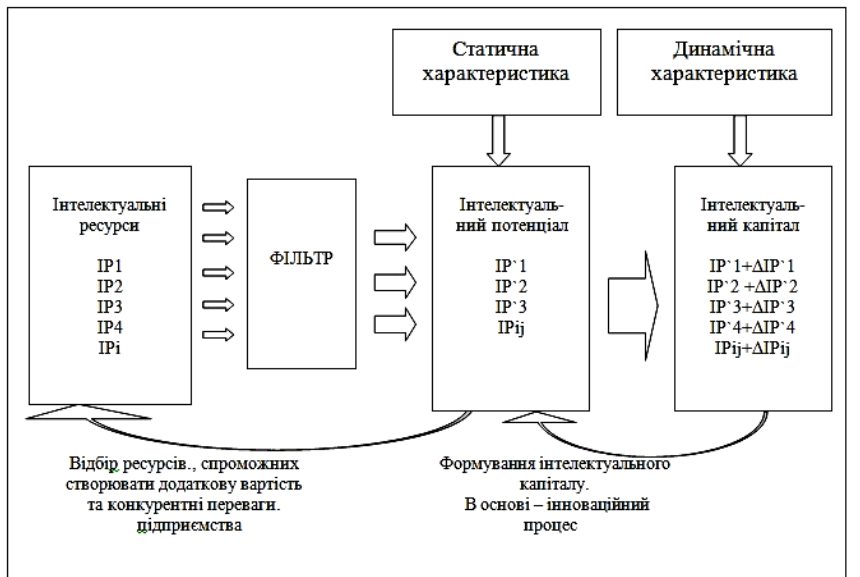

Рис. 1. Схема формування інтелектуального капіталу підприємницьких структур, запропонована К. В. Ковтуненко [10]

Можна підтримати В. Г. Дайнеко [11], що сучасні умови функціонування ринкових суб'єктів формують для підприємницьких структур альтернативні можливості накопичення інтелектуального капіталу, які мають різний рівень витрат i ефективності. Основною проблемою накопичення інтелектуального капіталу, яку виділяють в наукових працях [12], є здійснення економічного вибору між двома основними альтернативами: забезпеченням припливу інтелектуального капіталу ззовні $з$ подальшою його адаптацією і відповідними витратами або створенням інтелектуального капіталу усередині підприємницької структури за рахунок власних інвестицій, витрат інтелектуальної праці та ефективної організації відтворення знань.

Дослідження розвитку транснаціональних корпорацій [13] свідчить про те, що процеси глобалізації впливають на посиленні процесів інтерналізації накопичення інтелектуального капіталу, коли корпорації обирають варіант формування інтелектуального капіталу за рахунок власних ресурсів, виробляючи при цьому розвинену систему його накопичення і обміну (розподіли). На думку дослідників [11; 12], до основних форм інтерналізації накопичення інтелектуального капіталу транснаціональних корпорацій можна віднести:

1) систему підготовки і навчання персоналу;

2) розвиток науково-дослідних і дослідноконструкторських робіт (НДДКР);

3) внутрішній (внутрішньофірмовий) трансферт знань, навичок і ноу-хау;

4) підвищення ділової репутації корпорацій (їх іміджу), передусім на основі зростання цінності бренд-капіталу.

На нашу думку, накопичення інтелектуального капіталу транснаціональними корпораціями повинно здійснюватись за всіма складовими капіталу, та його примноження повинне здійснюватись в розрізі тих складових, які поступово втрачають свою цінність та, в свою чергу, можуть уповільнити зростання нової вартості та прибутку корпорації, або погіршать ринкові позиції.

Обмін (розподілення) є одним 3 важливих процесів управління інтелектуальним капіталом транснаціональних корпорацій. За твердженням В. А. Осипова [14], стратегія обміну інтелектуальним капіталом орієнтована на систематичний обмін, який відбувається в результаті формування складових капіталу, їх структурування, накопичення, зберігання та використання 3 метою чіткого та своєчасного їх розподілення між компаніями корпорації. Необхідно відмітити, що успішний міжнародний обмін складовими інтелектуального капіталу призводить до зростання конкурентних позицій транснаціональних корпорацій як на рівні національних економік, так i на міжнародних глобальних ринках. Тому, на нашу думку, обмін інтелектуальним капіталом транснаціональних корпорацій повинен здійснюватись відповідно до чітких стратегій, i управління цим процесом необхідно здійснювати в комплексі загальнокорпоративних управлінських рішень.

\section{6. Висновки}

В процесі дослідження висвітлено основні підходи до управління (формування, накопичення та обміну) інтелектуальним капіталом транснаціональних корпорацій. Запропоновано структуру інтелектуального капіталу транснаціональних корпорацій, сформовану 3 урахуванням основних наукових поглядів та вимог законодавства. Розглянуті теоретичні аспекти управління інтелектуальним капіталом транснаціональних корпорацій в подальшому будуть розглянуті на методологічному та прикладному рівнях.

\section{Література}

1. Чухно, А. Інтелектуальний капітал: сутність, форми і закономірності розвитку [Текст] / А. Чухно // Економіка України. - 2002. - № 1. - С. 16-27.

2. Волков, Д. Л. Оценивание интеллектуального капитала российских компаний [Текст] / Волков Д. Л., 
Гаранина Т. А. // Научные доклады. - 2006. - № 22(R). СПб.: НИИ менеджмента СПбГУ. - 30 с.

3. Edvinsson, L. Some perspectives on intangibles and intellectual capital 2000 [Text] / L. Edvinsson // Journal of Intellectual Capital. - 2000. - Vol. 1. №. 1. - P. 12-16. doi: $10.1108 / 14691930010371618$

4. Брукинг, Э. Интеллектуальный капитал / пер. с англ. под ред. Л.Н. Ковалик [Текст] / Э. Брукинг. - СПб : Питер, 2001. - 288 с.

5. Stewart, T. A. Intellectual Capital. The New Wealth of Organizations [Text] / T. A. Stewart // New York: Currency Doubleday. - 1997. - № 4. - P. 67.

6. Кравченко, С. I. Обліково-аналітичне забезпечення управління інтелектуальним капіталом [Текст] / С. I. Кравченко, О. В. Корнєва // Вісник Національного університету «Львівська політехніка». 2009. - № 647. - С. 393-398.

7. Шпак, Н. О. Сутність та класифікаційні ознаки інтелектуального капіталу підприємства [Текст] / Н. О. Шпак, Н. Б. Білоус // Вісник Нац. ун-ту Водного господарства та природокористування. Зб. наук. пр. - 2007. - Вип. 3 (39). - С. 334-341.

8. Филиппов, О. А. Интеллектуальный капитал как социальная основа устойчивых инновационных преимуществ компании [Текст] : автореф. дисс. ... канд. социолог. наук : 22.00.03 / О. А. Филиппов. - М., 2011. $30 \mathrm{c}$.

9. Олійник, О. М. Сутність та визначення поняття «інтелектуальний капітал підприємств залізничного транспорту» [Текст] / О. М. Олійник // Вісник економіки транспорту та промисловості. - 2012. - № 40. - С. 180 -187.

10. Ковтуненко, К. В. Основні підходи до формування інтелектуального капіталу: зміст та роль в інноваційному розвитку підприємства [Текст] / К. В. Ковтуненко // Економіка розвитку. - 2013. № 3 (67). - С. 59-62.

11. Дайнеко, В. Г. Интеллектуальный капитал: проблемы накопления и регулирования в экономике, основанной на знаниях [Текст] / В. Г. Дайнеко // Вестник ВГУ. Серия «Гуманитарные науки». - 2004. - № 1. C. 193-203.

12. Лукичева, Л. И. Внутрифирменное управление интеллектуальными активами [Текст] / Л. И. Лукичева, Д. Н. Егорычев. - М. : ООО «Омега-Л», 2004. - 192 с.

13. Transnational Corporations and Economic Development: From Internationalization to Globalization [Text] / eds. L. Cuyvers, F.De Beule. -Basingstoke, England; N.Y. : Palgrave Macmillan, 2007. - 558 p.

14. Осипов, В. А. Управление интеллектуальным капиталом в условия инновационного развития предприятия [Текст] : автореф. дисс. ... канд. екон. наук : 08.00.05 / В. А. Осипов. - СПб., 2004. - 18 с.

\section{References}

1. Chukhno, A. (2002). Intelektual'nyj kapital: sutnist', formy i zakonomirnosti rozvytku [Intellectual capital: essence, forms and conformities to law of development]. Ekonomika Ukrainy, 1, 16-27
2. Volkov, D. L. Garanina, T. A. (2006). Ocenivanie intellektual'nogo kapitala rossijskih kompanij [Evaluation of intellectual capital of the Russian companies]. NII menedzhmenta SPbGU, 22(R), $30 \mathrm{~s}$.

3. Edvinsson, L. (2000). Some perspectives on intangibles and intellectual capital 2000. Journal of Intellectual Capital, 1, 12-16. doi: 10.1108/14691930010371618

4. Bruking, Je. (2001). Intellektual'nyj capital [Intellectual Capital]. Piter, 288.

5. Stewart, T. A. (1997). Intellectual Capital. The New Wealth of Organizations. New York: Currency Doubleday, 4,67

6. Kravchenko, S. I. (2009). Oblikovo-analitychne zabezpechennia upravlinnia intelektual'nym kapitalom [Registration-analytical intellectual capital provision of management]. Visnyk Natsional'noho universytetu «L'vivs'ka politekhnika», 647, 393-398

7. Shpak, N. O., Bilous, N. B. (2007). Sutnist' ta klasyfikatsijni oznaky intelektual'noho kapitalu pidpryiemstva [Essence and classification signs of intellectual capital of enterprise]. Visnyk Nats. un-tu Vodnoho hospodarstva ta pryrodokorystuvannia. Zbirn. nauk. pr., 3 (39), 334-341

8. Filippov O. A. Intellektual'nyj kapital kak social'naja osnova ustojchivyh innovacionnyh preimushhestv kompanii [Intellectual capital as social basis of steady innovative advantages of company]. Moscow, 30.

9. Olijnyk, O. M. (2012). Sutnist' ta vyznachennia poniattia «intelektual'nyj kapital pidpryiemstv zaliznychnoho transportu» [Essence and determination of concept "intellectual capital of enterprises of railway transport"]. Visnyk ekonomiky transportu ta promyslovosti, 40, 180-187.

10. Kovtunenko, K. V. (2013). Osnovni pidkhody do formuvannia intelektual'noho kapitalu: zmist ta rol' $\mathrm{V}$ innovatsijnomu rozvytku pidpryiemstva [Basic approaches to forming of intellectual capital : maintenance and role in innovative development of enterprise]. Ekonomika rozvytku, 3 (67), 59-62

11. Dajneko, V. G. (2004). Intellektual'nyj kapital: problemy nakoplenija i regulirovanija $\mathrm{v}$ jekonomike, osnovannoj na znanijah [Intellectual capital: problems of accumulation and adjusting in the economy based on knowledge].Vestnik VGU. Serija «Gumanitarnye nauki», 1, 193-203

12. Lukicheva, L. I., Egorychev, D. N. (2004). Vnutrifirmennoe upravlenie intellektual'nymi aktivami [Internal management by intellectual assets]. Moscow, Russia: OOO «Omega-L», 192.

13. Cuyvers, L., Beule, F.De ed. (2007). Transnational Corporations and Economic Development: From Internationalization to Globalization. Basingstoke: Palgrave Macmillan, 558.

14. Osipov, V. A. (2004). Upravlenie intellektual'nym kapitalom $\mathrm{v}$ uslovijah innovacionnogo razvitija predprijatija [Management by an intellectual capital in the conditions of innovative development of enterprise]. Saint Petersburg, 18 
Панченко Эвелина Александровна, аспирант, кафедра международного менеджмента, Киевский Национальный Экономический Университет им. В. Гетьмана, 03680, Украина, Киев, проспект Победы, 54/1 E-mail: eve.panchenko@gmail.com

\title{
УДК: 658.14/17
}

\section{УДОСКОНАЛЕННЯ БАНКІВСЬКОЇ СИСТЕМИ УКРАЇНИ}

\author{
(ㄱ Л. І. Саченок, А. П. Нікітіна
}

У статті розглянуто основні проблеми розвитку банківської системи в банках Украӥни , проаналізовано чинники впливу на ї̈ розвиток. Визначено основні складові інноваційної діяльності в банківській сфері, наведено структуру управління інноваційним розвитком банківської системи. Розроблено загальну конщепцію управління інноваційним розвитком.

Ключові слова: інформаційні технології банківська система, інноваційний розвиток, банк, економіка глобалізації.

The article deals with the main problems of the banking system in Ukrainian banks, factors that influenced on its development are analyzed. The main components of innovative activity in the banking sector is determined, the structure of innovative development of the banking system is given. The general concept of innovative development is maked.

Keywords: information technologies; banking system; innovative development; bank; globalization economy

\section{1. Вступ}

В сьогоденних економічних умовах, які характеризуються, високими темпами розвитку інформаційних технологій i орієнтацією на розроблення, впровадження та використання високотехнологічної продукції, все більшого значення набувають питання інноваційного розвитку, побудови економіки знань і забезпечення ефективних фінансових та інформаційних комунікацій. На Міжнародній конференції з укріплення потенціалу у сфері комерціалізації й захисту інтелектуальної власності, що проходила в Москві в 2010 р. на це звертав увагу О. Хименко у доповіді «Реалізація інноваційної політики в Україні».

Формування інноваційної моделі розвитку економіки спрямоване на забезпечення реалізації науково-технічного, економічного та соціального потенціалу України, застосування інтелектуального й творчого потенціалу кадрових ресурсів, зменшення впливу тіньового сектору економіки, сприяння підвищенню соціального захисту населення.

Реалізація конкурентних переваг України у світовому господарстві можливе лише за рахунок впровадження пріоритетів розвитку науки, технологій, освіти та інтелектуального й соціального захисту людини як носія знань, потенційного впровадження інновацій. Це підтверджується визначеним переліком пріоритетних тематичних напрямів наукових досліджень [1], до складу якого входять теми, пов'язані 3 реалізацією заходів, спрямованих на всебічний розвиток людського потенціалу, підтримкою науково-технічної діяльності, організацією інформаційного менеджменту, модернізацією промисловості та орієнтацією іiі потужностей на нововведення, формування в суспільстві інноваційних потреб. Але для підтримки інноваційних перетворень необхідно зважати на те, що передумовою реалізації будь-яких управлінських впливів у науково-технічній сфері повинна бути чітко сформульована стратегія інноваційного розвитку, спрямована насамперед на активізацію внутрішніх i зовнішніх джерел фінансово-кредитного забезпечення інноваційної діяльності, що вимагає модернізації банківської системи як основного постачальника інвестиційних ресурсів для інноваційної діяльності суб'єктів господарювання[5]

\section{2. Постановка проблеми}

Одна 3 головних проблем, що заважає формуванню стратегії інноваційного розвитку банківської системи, пов'язана 3 труднощами оцінювання інноваційного потенціалу різних варіантів організаційно-економічного розвитку банків.. Тому необхідно провести структуризацію нововведень, що забезпечить вибір обгрунтованої стратегії розвитку банку, а також дозволить визначити характер майбутньої банківської діяльності, склад банківських операцій, форми обслуговування клієнтів тощо

Аналіз розвитку світової економіки свідчить про те, що банківська сфера стала однією з найбільш динамічних складових світового економічного простору оскільки глобалізація, розвиток інформаційних технологій i зростання нестабільності, що сьогодні характеризують розвиток світової економіки, особливо чітко знаходять своє відображення в банківській сфері, яка $\epsilon$ високочутливою до впливу зовнішніх чинників. У той же час банківська сфера все більш підтверджує свій статус як базова компонента інноваційного розвитку економіки, що здатна забезпечити його ефективність [5]. Як показано в [2], роль банківської системи в процесі інноваційних перетворень в економіці буде зростати i в подальшому. Це зумовлює необхідність дослідження напрямів стратегічного управління та пошуку інноваційних підходів щодо розвитку банківської системи. 